\title{
ANALISIS POLA KONVERSI LAHAN SAWAH DAN STRUKTUR HUBUNGAN PENYEBAB DAN PENCEGAHANNYA (STUDI KASUS KABUPATEN SUBANG, PROVINSI JAWA BARAT)
}

\author{
Analysis of Paddy Field Land Convertion Pattern and Its Structure of Cause Relations and \\ Preventions (Case Study of Subang District, West Java Province)
}

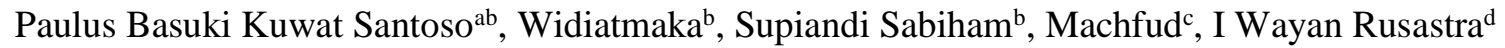 \\ a Program Pascasarjana Pengelolaan Sumberdaya Alam dan Lingkungan, Institut Pertanian Bogor, Indonesia - \\ pbksantoso@gmail.com \\ ${ }^{b}$ Departemen Ilmu tanah dan Sumberdaya lahan, Fakultas Pertanian, Institut Pertanian Bogor, Kampus IPB \\ Darmaga, Bogor 16680 \\ ${ }^{c}$ Departemen Teknologi Industri Pertanian, Fakultas Teknologi Pertanian, Institut Pertanian Bogorm, Kampus IPB \\ Darmaga, Bogor 16680 \\ ${ }^{\mathrm{d}}$ Pusat Sosial Ekonomi dan Kebijakan Pertanian, Kampus Penelitian Cimanggu, Jl. Tentara Pelajar No. 3 Bogor \\ 16111
}

\begin{abstract}
The extent of land use and land cover (LULC) of paddy field in Subang Regency has decreased because of the conversion into non-paddy field. The objectives of this research were to review the spatial pattern of LULC change, to analyze the cause and to identify the anticipation strategy of paddy field conversion. The analysis used the Landsat data of 1999, 2004, 2009, and 2014 which were interpreted by supervise technique. The interpretation result was compared with the existing LULC and was examined by Kappa methode. This research focuses on the spatial pattern of LULC change, integrated with the Interpretative Structural Modeling (ISM) to review the cause and the anticipation strategy of the conversion. The results revealed that the paddy field was converted into plantation, built-up area, and dryland agriculture. The ISM result revealed that the conversion causes were: (1) increasing the farmer economic needs, (2) increasing the built-up area, (3) increasing the selling price of land and (4) decreasing the farming motivation. To anticipate the conversion, several priorities are needed, namely (1) rehabilitation of the irrigation infrastructures and regulation of the spatial planning, (2) tighten the conversion permit and maximization of the abandoned land, and (3) giving the incentive and disincentive for the farmers, land consolidation, and establishment of corporate farming.
\end{abstract}

Keywords: ISM, GIS, land use, land cover

(Diterima: 25-02-2017; Disetujui: 19-04-2017)

\section{Pendahuluan}

Kabupaten Subang memiliki luas wilayah 205.176 hektar yang $41 \%$ atau seluas 84.570 hektar penggunaan lahannya untuk sawah (BPS Subang, 2014). Kabupaten Subang merupakan penyumbang kebutuhan beras terbesar ketiga di Jawa Barat (BPS Jabar, 2012), sementara Jawa Barat sendiri merupakan Provinsi penyumbang beras terbesar kedua nasional setelah Jawa Timur (BPS, 2015). Seperti halnya wilayahwilayah lain di Pulau Jawa, seiring dengan meningkatnya kebutuhan lahan non-pertanian, banyak lahan sawah di wilayah ini yang dikonversi menjadi penggunaan lain. Jika hal ini dibiarkan tanpa upaya pengendalian, sumbangan wilayah terhadap produksi beras nasional terancam berkurang (Prihatin, 2015).

Fenomena perubahan penggunaan lahan menjadi isu penting ketika kebutuhan akan lahan untuk tujuan tertentu tidak terpenuhi oleh ketersediaan lahannya. Secara teoritis, penggunaan lahan yang kurang menguntungkan secara ekonomi akan terkonversi menjadi penggunaan lahan lain yang lebih menguntungkan (Rustiadi et al., 2011). Penelitian perubahan penggunaan lahan dan tutupan lahan (PLTL) membutuhkan identifikasi pola perubahan penggunaan lahan (Beuchle et al., 2015; Ganasria dan Dwarakisha, 2015; Disperati dan Virdis, 2015; Zhu dan Woodcock 2014). Andalusia (2014) telah meneliti pola perubahan penggunaan lahan pertanian di Subang selama 20072013 serta mempelajari faktor-faktor yang mempengaruhi konversi lahan menggunakan regresi logistik. Widiatmaka et al. (2016) memetakan sumber daya lahan di Kabupaten Subang dengan mengevaluasi kesesuaian lahan pada setiap unit satuan tanah untuk merekomendasikan input bagi lahan sawah.

Secara fisik, pola perubahan penggunaan lahan dapat dideteksi dari suatu seri data spasial. Namun biasanya, penyebab perubahannya tidak dapat diketahui hanya dengan melihat data spasial termasuk dalam kurun waktu beberapa tahun karena kompleksnya permasalahan. Faktor-faktor penyebab terjadinya perubahan penggunaan lahan yang saling berinteraksi satu dengan lainnya menyebabkan kompleksitas dari struktur sistem perubahan penggunaan lahan (Attri et al., 2013).

Salah satu metodologi yang dapat digunakan untuk mengidentifikasi struktur dalam sistem yang sifatnya kompleks adalah Interpretative Structural Modelling 
(ISM) (Sohani dan Sohani, 2012). Jika ISM dapat dipadukan dengan analisis spasial perubahan penggunaan lahan, kemungkinan kompleksitas faktorfaktor penyebab perubahan penggunaan lahan dapat diurai.

Dalam suatu sistem yang kompleks, pengaruh dinamis elemen yang berbeda dapat dipertimbangkan dalam elemen-elemen yang saling terkait (Geoge \& Pramod, 2014). Pemahaman terhadap perilaku sistem membutuhkan identifikasi hubungan antar sub-elemen sistem dalam setiap elemen sistem (Eriyatno, 2013). Jadhav et al. (2015) memberikan arahan asumsi dalam pemodelan ISM, yaitu: (1) pemodel mempunyai pengetahuan dan pengalaman yang cukup tentang permasalahan; (2) terdapat hubungan kontekstual yang unik pada setiap pasangan variabel untuk mengembangkan Struktur Matrix Self-Interaksi (SSIM); (3) model suatu hubungan kontekstual adalah transitif dan bertingkat; (4) adanya reachability matrix untuk mengembangkan model struktural dari penyusunan perolehan data.

Beberapa peneliti menerapkan ISM untuk mengurai kompleksitas struktur sistem. Saxena et al. (1992) menerapkan ISM dalam industri semen di India untuk menentukan peubah kunci dalam pembangunan suatu skenario, mengidentifikasi pelaku, aktivitas, peran, aliansi, konflik, dan menganalisis pokok perubahan. Luthra et al. (2011) mengidentifikasi berbagai hambatan dalam pelaksanaan GSCM (Green Supply Chain Management) pada industri otomotif India. Sohani dan Sohani (2012) menggunakan ISM untuk mencari kerangka kualitas kerja suatu lembaga pendidikan tinggi untuk mengimbangi perkembangan yang terjadi. Sushil (2012) mengembangkan kerangka dan metodologi total pemodelan struktur interpretatif (TISM) yang merupakan konseptualisasi dan teori pembangunan dalam penelitian organisasi. Shahabadkar et al. (2012) menggunakan ISM untuk meningkatkan kinerja rantai pasok. Azar dan Bayat (2013) menggunakan ISM untuk memodelkan proses bisnis dalam suatu organisasi.

ISM membantu peneliti dalam hal: (1) pemahaman yang lebih baik, dan (2) pengenalan dengan jelas apa yang tidak diketahui (Geoge dan Pramod, 2014). ISM mengubah model mental yang tidak jelas dan kurang diartikulasikan dalam sistem menjadi model yang jelas untuk berbagai tujuan (Sushil, 2012; Eriyatno, 2013). Model struktural memotret perihal yang komplek dari suatu sistem dengan pola grafis dan kalimat (Janes, 1988; Eriyatno, 2013; Chen dan Wu, 2010; Lin dan Yeh, 2013; Khan dan Rahman, 2015).

Penelitian yang memadukan tentang metode perubahan penggunaan lahan menggunakan Geographic Information System (GIS) dan ISM belum banyak dilakukan. Penelitian ini mencoba menggabungkan kedua metodologi tersebut untuk mendapatkan faktor-faktor penyebab terjadinya perubahan penggunaan lahan sawah dan upaya pencegahannya.

Tujuan utama penelitian ini adalah untuk menyusun struktur hubungan penyebab terjadinya konversi lahan sawah dan strategi pencegahannya. Secara khusus, penelitian ini mempunyai dua tujuan, yaitu: (1) menentukan pola perubahan penggunaan lahan secara spasial, dan (2) menyusun sub-elemen penyebab terjadinya konversi lahan sawah dan sub-elemen strategi untuk mempertahankan lahan sawah agar tidak terkonversi ke penggunaan lainnya.

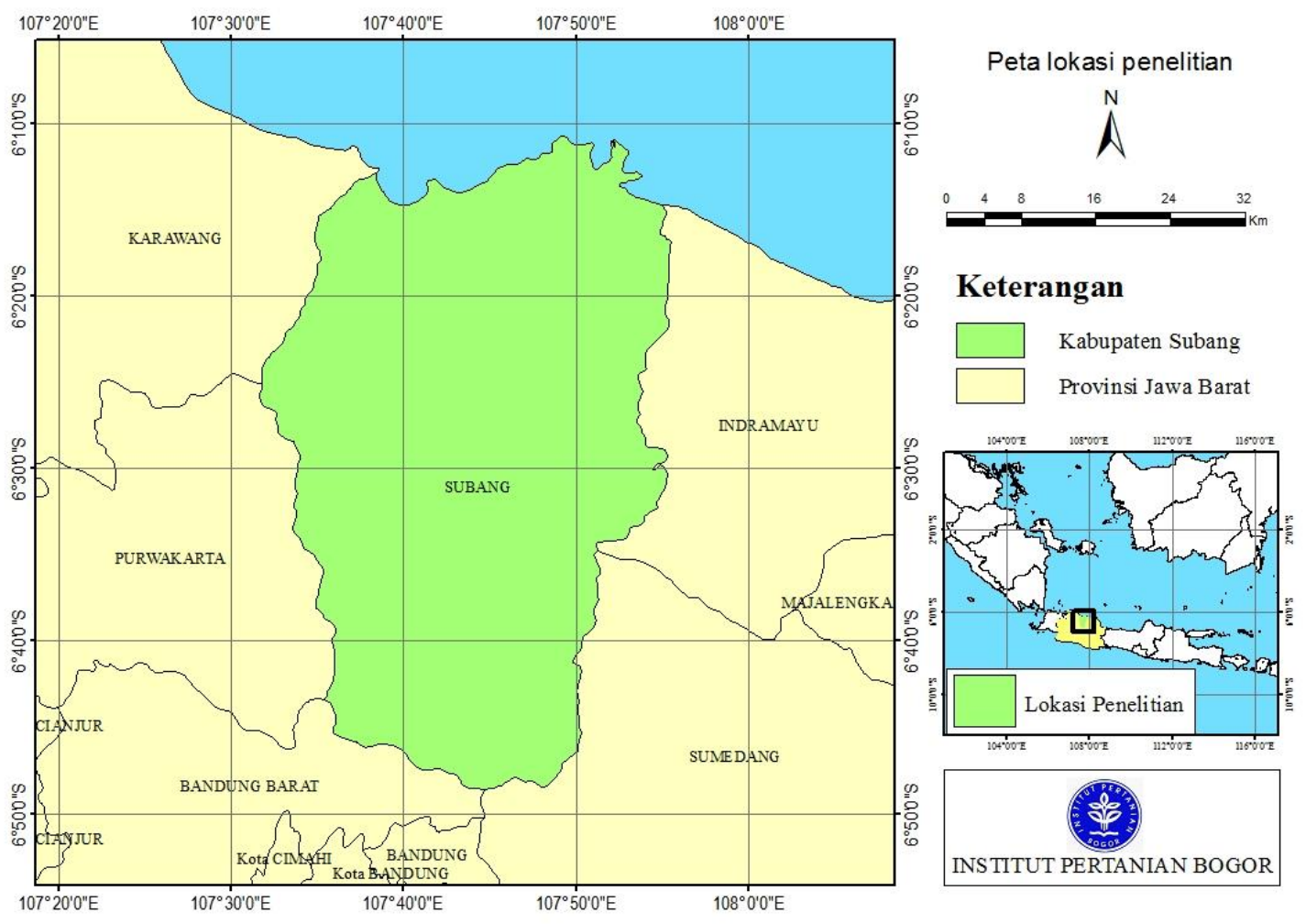

Gambar 1. Lokasi penelitian struktur hubungan penyebab dan pencegahan konversi lahan sawah di Kabupaten Subang 


\section{Metode Penelitian}

\section{a. Lokasi Penelitian}

Kabupaten Subang terletak pada posisi geografis $107^{\circ} 31^{\prime}-107^{\circ} 54^{\prime}$ Bujur Timur dan $6^{\circ} 11^{\prime}-6^{\circ} 49^{\prime}$ Lintang Selatan (Gambar 1). Berdasarkan topografinya, wilayah Kabupaten Subang mempunyai daerah pegunungan di bagian selatan dengan ketinggian antara $500-1.500$ meter di atas permukaan laut (dpl), daerah berbukit dan dataran di bagian tengah dengan ketinggian 50-500 meter dpl, dan daerah dataran rendah di bagian utara 0-50 meter dpl (BPS Subang, 2014). Sebagian besar wilayah (80\%) Kabupaten Subang memiliki tingkat kemiringan lereng $0^{\circ}-17^{\circ}, 11 \%$ wilayah memiliki tingkat kemiringan $18^{\circ}-45^{\circ}$, dan $9 \%$ wilayahnya memiliki kemiringan lebih dari $45^{\circ}$. Secara umum wilayah Kabupaten Subang beriklim tropis dengan curah hujan rata-rata per tahun $2.352 \mathrm{~mm}$ dengan jumlah hari hujan 100 hari (BPS Subang 2014). Sumber daya air dipenuhi dari 4 DAS (Daerah Aliran Sungai) yaitu: (1) DAS Cipunagara, (2) DAS Cilamaya, DAS Ciasem, dan DAS Cigadung (Bappeda Subang 2009).

\section{b. Data}

\section{Data spasial}

Deteksi pola perubahan PLTL dilakukan untuk selang waktu 15 tahun pada periode tahun 1999 sampai dengan tahun 2014 dengan mengambil rentang setiap 5 tahun yaitu tahun 1999, 2004, 2009, dan 2014. Format data yang digunakan adalah vektor dan raster. PLTL 1999 dibantu dengan data dari peta Rupa Bumi Indonesia (RBI) skala 1:25 000 pulau Jawa (Bakosurtanal 1999) yang telah diperbaharui kembali pada tahun 2014 (BIG, 2014). PLTL tahun 1999 dan 2014 menggunakan bahan dasar peta RBI dari unsur tema tutupan lahan. Data vektor tahun 2009 menggunakan peta tutupan lahan skala 1:50 000 yang dipublikasikan oleh Badan Pertanahan Nasional (BPN, 2009). Batas administrasi tingkat kabupaten menggunakan peta administrasi skala 1:25 000 (BIG, 2016). Data vektor yang digunakan dalam penelitian ini disajikan pada Tabel 1 .

Tabel 1. Ketersdian data vektor, skala data, dan sumber data

\begin{tabular}{llcl} 
Tahun & Skala & Data & Sumber \\
\hline 1999 & $1: 25000$ & RBI & BAKOSURTANAL \\
\hline 2009 & $1: 50000$ & $\begin{array}{c}\text { Tutupan } \\
\text { lahan }\end{array}$ & BPN \\
\hline 2014 & $1: 50000$ & $\begin{array}{c}\text { Tutupan } \\
\text { Lahan }\end{array}$ & BIG \\
\hline 2016 & $1: 25000$ & $\begin{array}{c}\text { Batas } \\
\text { administrasi }\end{array}$ & BIG \\
\hline
\end{tabular}

Data vektor PLTL tahun 2004 dilengkapi dengan interpretasi data raster citra Landsat akuisisi tahun 2004 pada path 122 dan row 64, 65. Landsat merekam permukaan bumi setiap 16 hari sekali pada lokasi yang sama. Adanya kandungan awan dalam citra mengakibatkan interpretasi citra menjadi kurang akurat, sehingga data dipilih hanya dari citra Landsat yang bebas dari awan di lokasi penelitian. Analisis pola perubahan PLTL juga menggunakan data raster Landsat untuk tahun akuisisi 1999, 2004, 2009, dan 2014. Landsat memiliki resolusi $30 \mathrm{~m}$ yang dapat digunakan untuk memetakan tutupan lahan pada skala 1:50.000. Identifikasi data Landsat disajikan pada Tabel 2.

Tabel 2. Data raster Landsat di lokasi penelitian yang digunakan

\begin{tabular}{lcc}
\hline \multicolumn{1}{c}{ Nama file } & Path/Row & $\begin{array}{c}\text { Waktu } \\
\text { perekaman }\end{array}$ \\
\hline LT51220641999231DKI00 & $122 / 64$ & 19-AUG-99 \\
\hline LT51220651999231DKI00 & $122 / 65$ & 19-AUG-99 \\
\hline LT51210641999240DKI00 & $121 / 64$ & 28-AUG-99 \\
\hline LT51220642004293BKT00 & $122 / 64$ & 19-OCT-04 \\
\hline LT51220652004293BKT00 & $122 / 65$ & 19-OCT-04 \\
\hline LT51210652009347BKT00 & $121 / 65$ & 13-DEC-09 \\
\hline LT51220642009338BKT00 & $122 / 64$ & 04-DEC-09 \\
\hline LT51220652009338BKT00 & $122 / 65$ & 04-DEC-09 \\
\hline LE71220652014344EDC00 & $122 / 65$ & 10-DEC-14 \\
\hline LE71220642014344EDC00 & $122 / 64$ & 10-DEC-14 \\
\hline LE71210642014065EDC00 & $121 / 64$ & 06-MAR-14 \\
\hline Sumber: www.earthexplorer.usgs.gov diunduh 8 Agustus 2015
\end{tabular}

\section{Data non Spasial}

Data yang digunakan untuk identifikasi struktur penyebab dan pencegahan konversi PLTL sawah adalah sub-elemen yang merupakan hasil dari kegiatan Focus Group Discussion (FGD). FGD mempunyai tujuan untuk memperoleh faktor penyebab dan pencegahan konversi lahan sawah di Kabupaten Subang. FGD dilaksanakan pada bulan Agustus 2016 dengan peserta sebanyak orang, meliputi perwakilan dari Tani Nelayan Andalan (KTNA) Kabupaten Subang, Perkumpulan Petani Pengguna Air (P3A). Sub-elemen hasil FGD diperkuat dengan referensi hasil penelitian dari peneliti sebelumnya. Penyebab terjadinya konversi PLTL sawah mempunyai 8 subelemen yang kemudian distrukturkan melalui pendapat para pakar. Ke-8 sub-elemen penyebab terjadinya konversi PLTL sawah disajikan pada Tabel 3.

Sub-elemen strategi pengendalian konversi PLTL sawah yang dihasilkan oleh kegiatan FGD juga diperkuat oleh literatur dari penelitian sejenis yang telah dilakukan. Hasil indentifikasi FGD dan studi literatur menghasilkan 7 sub-elemen strategi pengendalian konversi PLTL sawah di kabupaten Subang. Ke-7 sub-elemen strategi pengendalian konversi PLTL sawah disajikan pada Tabel 4.

\section{c. Metode Analisis}

Penentuan pola perubahan penggunaan lahan sawah pada tujuan pertama merupakan kajian yang membutuhkan data spasial eksisting dari beberapa tahun sebelumnya. SIG digunakan untuk mengelola pola perubahan lahan secara spasial. Sedangkan tujuan kedua menggunakan data hasil pendapat 3 pakar yang diperoleh melalui FGD. Masing-masing tujuan mempunyai tahapan tersendiri. Hasil dari masingmasing tahapan merupakan materi yang dianalisis 
untuk menghasilkan struktur hubungan faktor pengendali pada pola perubahan penggunaan lahan sawah. Gambar 2 menjelaskan proses terbentuknya struktur faktor pengendali pada pola perubahan penggunaan lahan sawah dengan ISM dan GIS.

Tabel 3. Sub-elemen penyebab terjadinya konversi PLTL sawah

\begin{tabular}{|c|c|c|}
\hline Kode & Sub-Elemen & Referensi \\
\hline A1 & Pertumbuhan industri & $\begin{array}{l}\text { FGD (2016); Prihatin (2015); } \\
\text { Kulsum et al. (2015); Andalusia et } \\
\text { al. (2014) }\end{array}$ \\
\hline A2 & $\begin{array}{l}\text { Pertumbuhan pusat } \\
\text { ekonomi baru }\end{array}$ & $\begin{array}{l}\text { FGD (2016), Pewista dan Harini } \\
\text { (2013); Zakaria dan Rachman } \\
\text { (2013); Irawan (2005) }\end{array}$ \\
\hline A3 & $\begin{array}{l}\text { Pertumbuhan } \\
\text { perumahan }\end{array}$ & $\begin{array}{l}\text { FGD (2016), Jauhari dan } \\
\text { Ritohardoyo (2013); Andalusia et } \\
\text { al. (2014); Prihatin (2015) }\end{array}$ \\
\hline A4 & $\begin{array}{l}\text { Pertumbuhan jalur } \\
\text { transportasi }\end{array}$ & $\begin{array}{l}\text { FGD (2016); Andalusia et al. } \\
\text { (2014); Widiatmaka et al. (2013) }\end{array}$ \\
\hline A5 & $\begin{array}{l}\text { Peningkatan } \\
\text { kebutuhan ekonomi } \\
\text { petani }\end{array}$ & $\begin{array}{l}\text { FGD (2016); Kulsum et al. } \\
\text { (2015); Pewista dan Harini } \\
\text { (2013); Zakaria dan Rachman } \\
\text { (2013); Irawan (2005) }\end{array}$ \\
\hline A6 & $\begin{array}{l}\text { Peningkatan harga jual } \\
\text { lahan }\end{array}$ & $\begin{array}{l}\text { FGD (2016); Kulsum et al. } \\
\text { (2015); Pewista dan Harini } \\
\text { (2013); Zakaria dan Rachman } \\
\text { (2013) }\end{array}$ \\
\hline A7 & $\begin{array}{lr}\text { Peningkatan } & \\
\text { perubahan } & \text { status } \\
\text { kepemilikan lahan } \\
\text { sawah (bagi waris } \\
\text { (Fragmentasi lahan), } \\
\text { Jual beli) }\end{array}$ & $\begin{array}{l}\text { FGD (2016), Isa (2006); Darwis } \\
\text { (2008) }\end{array}$ \\
\hline A8 & $\begin{array}{l}\text { Penurunan minat } \\
\text { generasi penerus } \\
\text { terhadap pertanian } \\
\text { (Tidak ada penggarap/ } \\
\text { tenaga kerja) }\end{array}$ & $\begin{array}{l}\text { FGD (2016), Suradisastra dan } \\
\text { Saliem (2011) }\end{array}$ \\
\hline
\end{tabular}

Analisis perubahan penggunaan lahan dari tahun 1999 sampai dengan 2014 menggunakan data vektor tutupan lahan pada tahun 1999, 2004, 2009, dan 2014. Interpretasi kelas PLTL tahun 1999, 2009, dan 2014 dilakukan dengan metode klasifikasi terbimbing pada citra Landsat tahun yang berkesuaian. Hasil klasifikasi dibandingkan dengan data PLTL yang tersedia pada tahun yang sama. Hasil klasifikasi dibandingkan dengan dengan data yang tersedia menggunakan metode perbandingan Kappa. Analisis Kappa merupakan teknik multivariate diskrit yang digunakan dalam penilaian akurasi secara statistik pada matriks kesalahan yang diuji perbedaannya secara statistik dari matriks lainnya (Congalton dan Green, 2008). Tutupan lahan tahun 2004 hasil klasifikasi terbimbing tidak dibandingkan dengan peta eksisting tahun 2004 karena peta eksisting tutupan lahan tidak tersedia. Validasi hasil klasifikasi terbimbing citra Landsat tahun 2004 dilakukan menggunakan overlay dari ketiga data hasil klasifikasi tahun 1999, 2009, dan 2014. Deliniasi PLTL 2004 menggunakan pola warna untuk setiap kelas tutupan lahan yang secara visual diperoleh dari overlay
PLTL 1999 dengan citra Landsat 1999, PLTL 2009 dengan citra Landsat 2009, dan PLTL 2014 dengan citra Landsat 2014 (Gambar 3).

\begin{tabular}{|c|c|c|}
\hline Kode & Sub-Elemen & Referensi \\
\hline B1 & $\begin{array}{l}\text { Menetapkan dan } \\
\text { melaksanakan Perda } \\
\text { tata ruang }\end{array}$ & $\begin{array}{l}\text { FGD (2016); Andalusia et al. } \\
\text { (2014); Sumaryanto et al. } \\
\text { (2001) }\end{array}$ \\
\hline B2 & $\begin{array}{l}\text { Mengkonsolidasi } \\
\text { lahan sawah }\end{array}$ & $\begin{array}{l}\text { FGD (2016); Sinuraya et al. } \\
\text { (2011); Darwis (2008) }\end{array}$ \\
\hline B3 & $\begin{array}{l}\text { Membangun dan } \\
\text { merehabilitasi } \\
\text { Infrastruktur } \\
\text { jaringan irigasi }\end{array}$ & $\begin{array}{l}\text { FGD (2016); Prihatin (2015); } \\
\text { Kusumaningtyas dan Chofan } \\
\text { (2013); Pasandaran (2006) }\end{array}$ \\
\hline B4 & $\begin{array}{l}\text { Memanfaatkan } \\
\text { lahan terlantar/ tidak } \\
\text { produktif untuk non } \\
\text { pertanian }\end{array}$ & FGD (2016) \\
\hline B5 & $\begin{array}{l}\text { Membentuk Usaha } \\
\text { bersama padi }\end{array}$ & FGD (2016); Asmani (2013) \\
\hline B6 & $\begin{array}{l}\text { Memberikan } \\
\text { Isentif/Disinsentif }\end{array}$ & $\begin{array}{l}\text { FGD (2016); Kulsum et al. } \\
\text { (2015); Zakaria dan Rachman } \\
\text { (2013); Peraturan Pemerintah } \\
\text { Nomor 12 Tahun 2012; } \\
\text { Undang-Undang Nomor 41 } \\
\text { Tahun 2009, Pasandaran } \\
\text { (2006); Sudaryanto dan } \\
\text { Rusastra (2006) }\end{array}$ \\
\hline B7 & $\begin{array}{l}\text { Memperketat } \text { ijin } \\
\text { alih fungsi lahan } \\
\text { sawah }\end{array}$ & $\begin{array}{l}\text { FGD (2016); Muta'ali } \\
\text { (2013); Ashari (2003) }\end{array}$ \\
\hline
\end{tabular}

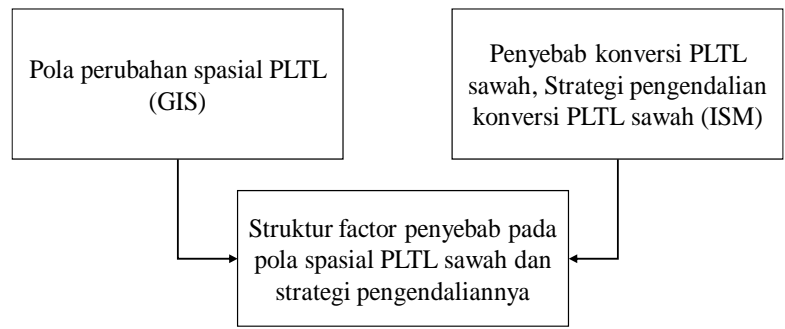

Gambar 2. Metode analisis untuk memperoleh struktur faktor penyebab konversi PLTL sawah dan strategi pengendaliannya, 2016

Studi ini menetapkan 8 kelas tutupan lahan yaitu: hutan, semak belukar, perkebunan, tegalan/ladang, sawah, kawasan terbangun, tubuh air, dan tambak (Tabel 5). Analisis perubahan PLTL ini menggunakan data dalam bentuk raster karena dalam simulasi penelitian selanjutnya data raster yang sama yang akan digunakan. Karena itu, data vektor yang tersedia ditransfer ke dalam format raster. Wilayah studi dibagi dalam sel-sel dengan ukuran 15 meter x 15 meter (luas $255 \mathrm{~m}^{2}$ ) dan menghasilkan grid sebanyak $9694688 \mathrm{sel}$ dengan luas total 218129 hektar. Analisis berikutnya yang dilakukan adalah menghitung jumlah sel dalam setiap kelas tutupan lahan untuk PLTL tahun 1999, 2004, 2009, dan 2014. Hasil tersebut ditabulasikan dan dibandingkan dalam bentuk matriks konfusi. 
Tabel 5. Klasifikasi PLTL di Kabupaten Subang, 2016

\begin{tabular}{lll}
\hline Kode & PLTL analisis & PLTL sebelumnya \\
\hline 1 & Hutan & Hutan \\
\hline 2 & Semak belukar & $\begin{array}{l}\text { Belukar, semak, rumput, tanah } \\
\text { kososng }\end{array}$ \\
\hline 3 & Perkebunan & $\begin{array}{l}\text { Kebun campuran, perkebunan } \\
\text { besar, perkebunan rakyat }\end{array}$ \\
\hline 4 & Tegalan/Ladang & \\
\hline 5 & Sawah & $\begin{array}{l}\text { Sawah irigasi teknis, sawah tadah } \\
\text { hujan }\end{array}$ \\
\hline 6 & Kawasan & Pemukiman, industri, gedung \\
\hline 8 & Terbangun & Sungai, waduk, danau, situ \\
\hline
\end{tabular}

Analisis pola perubahan PLTL memerlukan identifikasi dinamika penyebab perubahan penggunaannya dan strategi pencegahannya (Terra et al., 2014). Metode analisis untuk memperoleh subelemen kunci dari penyebab terjadinya perubahan penggunaan lahan sawah dan strategi pencegahannya menggunakan ISM yang langkah-langkahnya diadopsi dari Janes (1988), Kannan et al. (2009), Govindan et al. (2010), Jadhav (2015) yaitu:

1. Mengidentifikasi penyebab dan strategi pencegahan perubahan penggunaan lahan sawah dengan melakukan Focus Group Discussion (FGD). FGD dilaksanakan pada tanggal 24 Agustus 2016.

2. Merangkum hasil FGD dan memadukannya dengan literature review untuk menghasilkan elemen dan sub-elemen kunci dari penyebab konversi lahan sawah dan strategi penanggulangannya.

3. Menentukan hubungan kontekstual penyebab terjadinya konversi lahan sawah dan strategi pencegahannya

4. Menyusun struktur self-interaksi matriks (SSIM) yang menunjukkan hubungan berpasangan antar sub-elemen
5. Melakukan FGD untuk memperoleh pendapat pakar dan menghasilkan konsensus jawaban antar pakar yang berbeda menjadi satu jawaban. FGD melibatkan seorang pakar ekonomi, seorang pakar pertanian, dan seorang praktisi (wakil dari KTNA).

6. Menyusun reachability matrix berdasarkan SSIM dan memeriksa transitivitas dan tingkat konsistensinya

7. Menyusun struktur penyebab terjadinya konversi penggunaan lahan sawah dan strategi pencegahannya.

Fokus dari penelitian ini adalah menentukan elemen kunci tentang: (1) kendala utama (penyebab) berubahnya penggunaan lahan sawah dengan hubungan kontekstual yang "menyebabkan"; dan (2) aktivitas, strategi dan cara mempertahankan lahan sawah dengan hubungan kontekstual tingkat kepentingan. Hubungan kontekstual antar sub-elemen dituangkan pada matriks perbandingan berpasangan menggunakan simbol V, A, $\mathrm{X}$, dan $\mathrm{O}$, yang memiliki makna sebagai berikut:

8. $\mathrm{V}$ jika eij $=1$ dan eji $=0 ; \mathrm{V}=$ sub-elemen ke-i lebih berperan dibandingkan sub-elemen ke-j dan tidak sebaliknya

9. A jika eij $=0$ dan eji $=1 ; A=$ sub-elemen $k e-j$ lebih berperan dibandingkan sub-elemen ke-i dan tidak sebaliknya

10. $\mathrm{X}$ jika eij $=1$ dan eji $=1 ; \mathrm{X}=$ kedua sub-elemen mempunyai nilai tingkat peran yang sama dan saling terkait

11. $\mathrm{O}$ jika eij $=0$ dan eji $=0 ; \mathrm{O}=$ kedua sub-elemen tidak saling terkait.

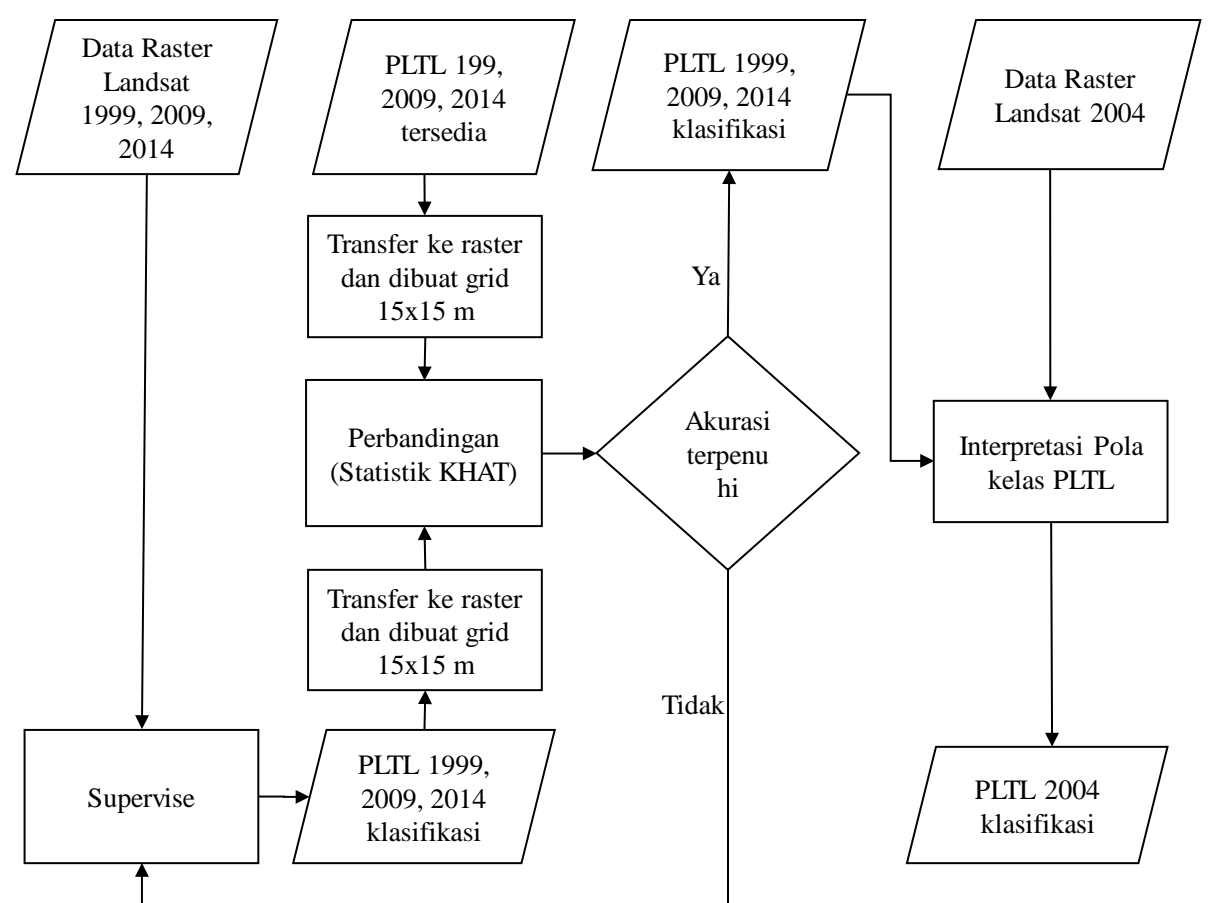

Gambar 3. Tahapan untuk memperoleh data vektor tutupan lahan dari pola kelas tutupan lahan di Kabupaten Subang, 2016 


\section{Hasil dan Pembahasan}

\subsection{Dinamika pola perubahan PLTL sawah}

Secara visual, hasil interpretasi citra untuk PLTL tahun 1999, 2004, 2009, dan 2014 menunjukkan bahwa penggunaan lahan sawah mendominasi wilayah penelitian dibandingkan 7 kelas PLTL lainnya (Gambar 4). Dinamika PLTL sawah mempunyai tren penurunan komposisi, yaitu: $54,32 \%$ atau 118.494 hektar pada tahun 1999 menjadi 44,20\% atau 96.422 hektar pada tahun 2004, 43,95\% atau 95.869 hektar pada tahun 2009, dan 43,70\% atau 95.320 hektar pada tahun 2014 (Tabel 6).

Analisis dinamika spasial PLTL di Kabupaten Subang periode 1999-2014 menunjukkan bahwa luas PLTL hutan bertambah 3.068 hektar dengan laju pertambahan 205 hektar per tahun. PLTL semak berkurang 1.589 hektar dengan laju pengurangan 106 hektar per tahun. PLTL perkebunan bertambah 6.629 hektar dengan laju pertambahan seluas 442 hektar per tahun. PLTL tegalan/ladang bertambah menjadi 8.139 hektar dengan laju pertambahan 543 hektar per tahun. PLTL sawah berkurang 23.713 hektar dengan laju pengurangan 1.545 hektar per tahun. PLTL kawasan terbangun bertambah 6.367 hektar dengan laju penambahan 424 hektar per tahun. PLTL luas tambak
560 hektar dengan laju penambahan 37 hektar per tahun. Dinamika perubahan PLTL periode 1999-2014 disajikan pada Tabel 8.

Penurunan komposisi jumlah sel PLTL sawah merupakan akibat dari berubahnya PLTL sawah menjadi perkebunan, lahan terbangun, tegal/ladang, hutan, semak, dan tambak. Perubahan kecil juga terjadi dari tutupan lahan hutan dan ladang. Penurunan komposisi jumlah sel PLTL sawah merupakan akibat bertambahnya jumlah sel hutan, semak, perkebunan, tegalan, dan tambak. Sebaliknya terdapat lokasi hutan dan tambak yang berubah menjadi sel PLTL sawah meskipun komposisinya relatif kecil. Pada periode tahun 2009-2014, sel PLTL sawah menurun dan berubah menjadi sel PLTL hutan, perkebunan, tegalan, dan tambak. Namun pada periode 2009-2014, sel PLTL sawah bertambah sebagai akibat berkurangnya sel PLTL hutan, perkebunan, tegalan, dan lahan terbangun (Tabel 7). Sumaryanto et al., (2001) mengemukakan bahwa sebagian dari lahan sawah yang terkonversi itu beralih fungsi menjadi lahan pertanian lahan kering, dan sebagian lainnya beralih fungsi ke penggunaan non-pertanian untuk memenuhi kebutuhan pemukiman, pengembangan industri, jasa, dan lain sebagainya.

Tabel 6. Jumlah sel setiap kelas tutupan lahan tahun 1999, 2004, 2009, 2014

\begin{tabular}{lrrrrrrrr}
\hline \multirow{2}{*}{ PLTL } & \multicolumn{1}{c}{$\mathbf{1 9 9 9}$} & \multicolumn{2}{c}{$\mathbf{2 0 0 4}$} & \multicolumn{2}{c}{$\mathbf{2 0 0 9}$} & \multicolumn{2}{c}{$\mathbf{2 0 1 4}$} \\
\cline { 2 - 9 } & Sel & $\mathbf{\%}$ & Sel & \% & Sel & \% & Sel & \% \\
\hline Hutan & 805.790 & 8,31 & 882.030 & 9,10 & 952.683 & 9,83 & 942.141 & 9,72 \\
\hline Semak & 177.898 & 1,84 & 108.004 & 1,11 & 107.419 & 1,11 & 107.262 & 1,11 \\
\hline Perkebunan & 1.591 .940 & 16,42 & 1.914 .499 & 19,75 & 1.914 .816 & 19,75 & 1.886 .540 & 19,46 \\
\hline Tegalan/Ladang & 790.218 & 8,15 & 1.164 .586 & 12,01 & 1.183 .614 & 12,21 & 1.151 .953 & 11,88 \\
\hline Sawah & 5.266 .381 & 54,32 & 4.285 .424 & 44,20 & 4.260 .840 & 43,95 & 4.236 .465 & 43,70 \\
\hline Kawasan Terbangun & 603.603 & 6,23 & 786.707 & 8,11 & 807.244 & 8,33 & 886.577 & 9,14 \\
\hline Sungai/Danau/Situ & 104.926 & 1,08 & 104.926 & 1,08 & 104.926 & 1,08 & 104.926 & 1,08 \\
\hline Tambak & 353.932 & 3,65 & 448.512 & 4,63 & 363.146 & 3,75 & 378.824 & 3,91 \\
\hline Total & 9.694 .688 & & 9.694 .688 & & 9.694 .688 & & 9.694 .688 & \\
\hline
\end{tabular}

Tabel 7. Pengurangan dan penambahan sel sawah

\begin{tabular}{|c|c|c|c|c|c|c|}
\hline Periode & \multicolumn{2}{|c|}{ 1999-2004 } & \multicolumn{2}{|c|}{ 2004-2009 } & \multicolumn{2}{|c|}{ 2009-2014 } \\
\hline PLTL & Pengurangan & Penambahan & Pengurangan & Penambahan & Pengurangan & Penambahan \\
\hline Hutan & 40.261 & 329 & 39.285 & 352 & 431 & 8.685 \\
\hline Semak & 17.748 & 4 & 17.697 & - & - & - \\
\hline Perkebunan & 404.818 & 13.180 & 407.413 & - & 9 & 237 \\
\hline Tegalan/ Ladang & 329.271 & 236 & 332.926 & - & 3.803 & 2.955 \\
\hline Kawsan Terbangun & 209.053 & 16.213 & 214.033 & - & 35.049 & 3.226 \\
\hline Tambak & 9.768 & - & 9.221 & 7 & 186 & - \\
\hline Jumlah & 1.010 .919 & 29.962 & 1.020 .575 & 352 & 39.478 & 15.103 \\
\hline User Accuracy & & & & & & \\
\hline Overal Accuracy & & & & & & \\
\hline
\end{tabular}


ISSN 2086-4639 | e-ISSN 2460-5824ＪPSL Vol. 7 (2): 184-194

Tabel 8. Dinamika perubahan PLTL dari tahun 1999-2014

\begin{tabular}{ccccc}
\hline PLTL & $\begin{array}{c}\text { Perubahan jumlah } \\
\text { sel } \\
(\text { sel })\end{array}$ & $\begin{array}{c}\text { Perubahan Luas } \\
\text { (hektar) }\end{array}$ & $\begin{array}{c}\text { Laju perubahan } \\
\text { (hektar/tahun) }\end{array}$ & Keterangan \\
\hline Hutan & $-136,351$ & $-3,068$ & -205 & bertambah \\
\hline Semak & 70.636 & 1.589 & 106 & berkurang \\
\hline Perkebunan & -294.600 & -6.629 & -442 & bertambah \\
\hline Tegalan/Ladang & -361.735 & 8.139 & -543 & bertambah \\
\hline Sawah & 1.029 .916 & 23.173 & 1.545 & berkurang \\
\hline Kawasan Terbangun & -282.974 & -6.367 & -424 & bertambah \\
\hline Tambak & -24.892 & -560 & -37 & bertambah \\
\hline
\end{tabular}

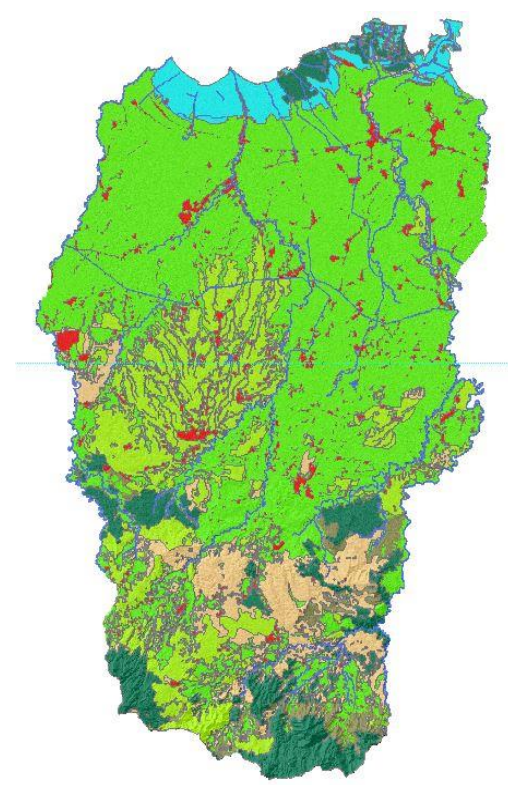

a

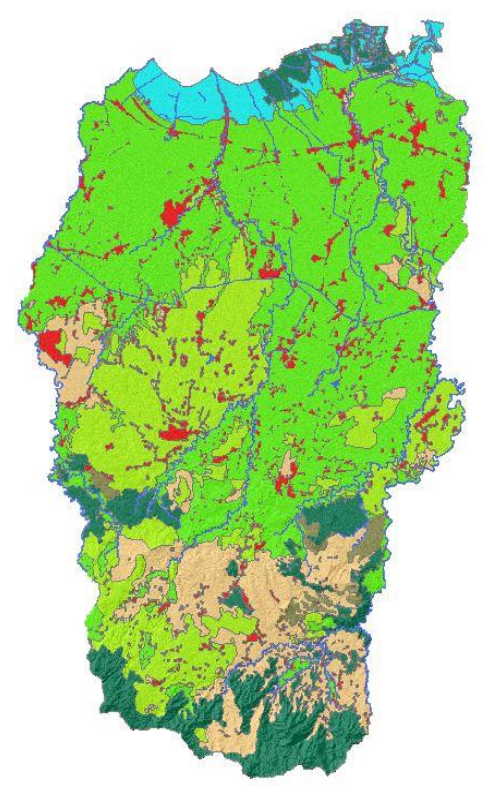

c

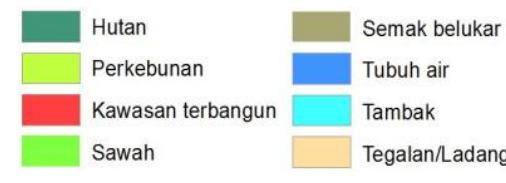

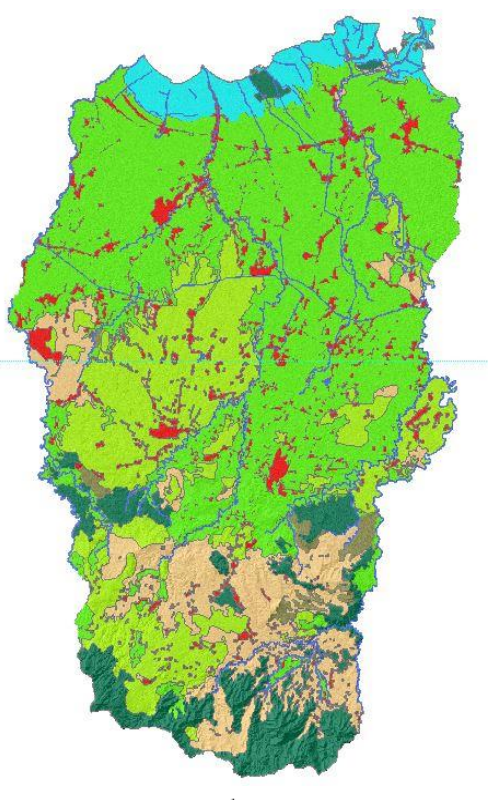

b

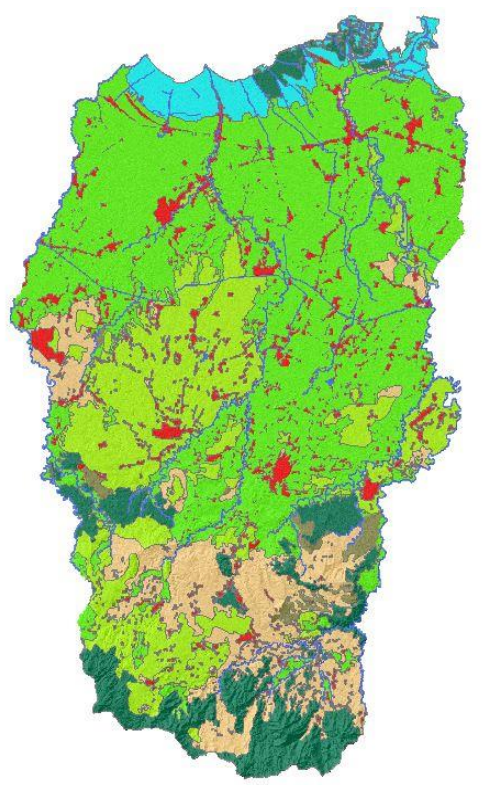

d

N

9,5

Gambar 4. (a) PLTL 1999, (b) PLTL 2004, (c) PLTL 2009, (d) PLTL 2014 Kabupaten Subang hasil analisis 2016 


\subsection{Struktur faktor penyebab konversi PLTL sawah}

Dari hasil identifikasi melalui FGD, diperoleh 8 faktor utama penyebab terjadinya konversi PLTL sawah ke PLTL lainnya (Tabel 3) dan 7 strategi pengendalian agar PLTL tidak terkonversi ke PLTL lainnya (Tabel 4). Andalusia et al., (2014); Ashari (2003); Asmani (2013); Darwis (2008); Kulsum et al. (2015); Kusumaningtyas dan Chofan (2013); Pasandaran (2006); Prihatin (2015); Sinuraya et al. (2011); Sudaryanto dan Rusastra (2006); Sumaryanto et al. (2001); Zakaria dan Rachman (2013) memperkuat penentuan faktor penyebab konversi PLTL sawah dalam penelitian ini.

Hasil pengelompokan sub-elemen pada elemen penyebab terjadinya konversi PLTL sawah menempatkan sub-elemen dalam 3 kelompok (Gambar 5). Kelompok pertama adalah sub-elemen peningkatan kebutuhan petani dengan daya dorong yang kuat namun tingkat ketergantungannya rendah terhadap sub-elemen lainnya. Pengaruh yang kuat dari sub-elemen peningkatan kebutuhan petani terhadap sub-elemen lainnya merupakan elemen kunci (Gambar 6) terjadinya konversi PLTL sawah. Hal tersebut diperkuat oleh pendapat Irawan (2005) dan Jauhari dan Ritohardoyo (2013) yang menyatakan bahwa faktor sosial dan ekonomi petani akan memicu terjadinya konversi lahan sawah. Pewista dan Harini (2013) mengemukakan bahwa petani, terutama bagi mereka yang mengandalkan usahanya di lahan yang sempit, penghasilannya kurang dapat mencukupi kebutuhannya. Hal ini merupakan akibat terbatasnya sumberdaya lahan untuk dikembangkan bagi kegiatan pertanian, karena rata-rata penguasaan lahan pertanian yang

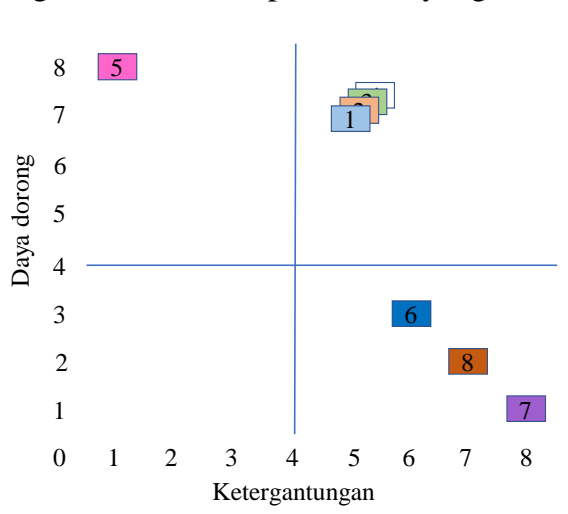

sempit dan tidak mampu mencapai skala usaha ekonomis (Zakaria dan Rachman 2013; Pewista dan Harini 2013). Faktor tingkat pendapatan petani mempengaruhi keputusan petani dalam konversi PLTL sawahnya sebagai akibat faktor eksternal (pajak lahan, harga jual lahan) dan faktor internal (tingkat pendapatan rumah tangga, luas lahan, status lahan) (Kulsum et al., 2015).

Di Kabupaten Subang, petani mengimbangi kebutuhan ekonominya antara lain dengan mengusahakan lahannya untuk komoditas yang lebih menguntungkan seperti tebu. Keputusan tersebut mengakibatkan konversi PLTL sawah menjadi PLTL perkebunan (Tabel 7). Kedua, kelompok sub-elemen yang mempunyai tingkat pengaruh yang tinggi dan tingkat ketergantungannya juga relatif tinggi terhadap sub-elemen lainnya, yaitu pertumbuhan industri, pertumbuhan pusat ekonomi baru, pertumbuhan perumahan, dan pertumbuhan jalur transportasi. Subelemen tersebut dalam kelas PLTL dikelompokkan menjadi kawasan terbangun. Secara visual, kawasan terbangun mempunyai kecenderungan peningkatan jumlah sel yang merupakan konversi dari sel sawah (Tabel 7). Perubahan PLTL sawah ke PLTL lainnya mendominasi dinamika perubahan PLTL di Kabupaten Subang (Tabel 7). Penurunan luas PLTL sawah diakibatkan oleh penyediaan kawasan terbangun untuk industri, pemukiman, maupun jasa lainnya (Andalusia et al. 2014). Penurunan luas PLTL sawah menjadi lahan terbangun terjadi hampir di seluruh wilayah Subang dengan perubahan terbesar di bagian tengah yaitu di Kecamatan Subang, Pabuaran dan Pagaden (Andalusisa et al. 2014).

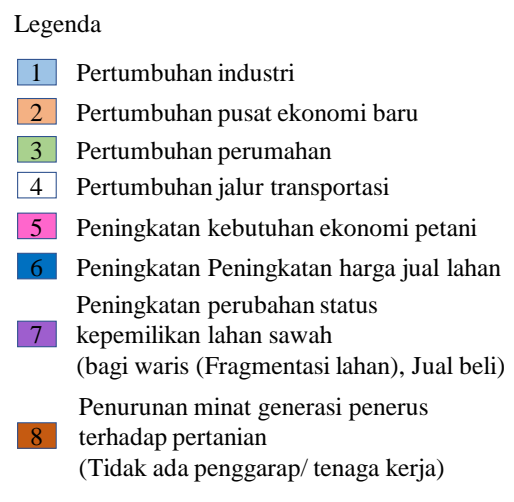

Gambar 5. Diagram pengelompokan sub-elemen dari penyebab konversi PLTL sawah hasil analisis 2016

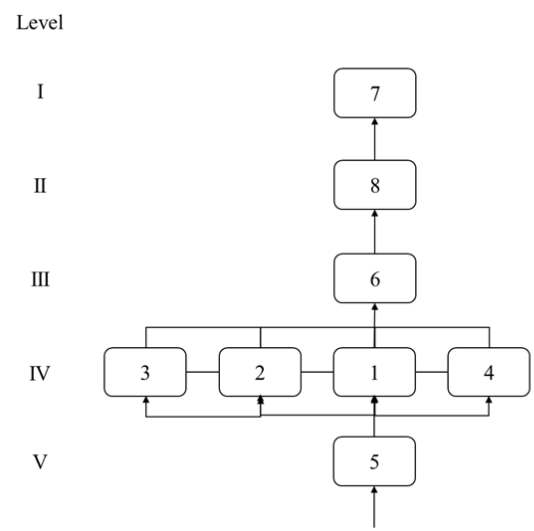

Legenda

1 Pertumbuhan industri

2 Pertumbuhan pusat ekonomi baru

3 Pertumbuhan perumahan

4 Pertumbuhan jalur transportasi

5 Peningkatan kebutuhan ekonomi petan

6 Peningkatan harga jual lahan

7 Peningkatan perubahan status kepemilikan lahan

sawah (bagi waris (fragmentasi lahan), jual beli)

8 Penurunan minat generasi penerus terhadap

pertanian (tidak ada penggarap/tenaga kerja)

Gambar 6. Model struktur sub elemen kunci penyebab terjadinya konversi lahan sawah 


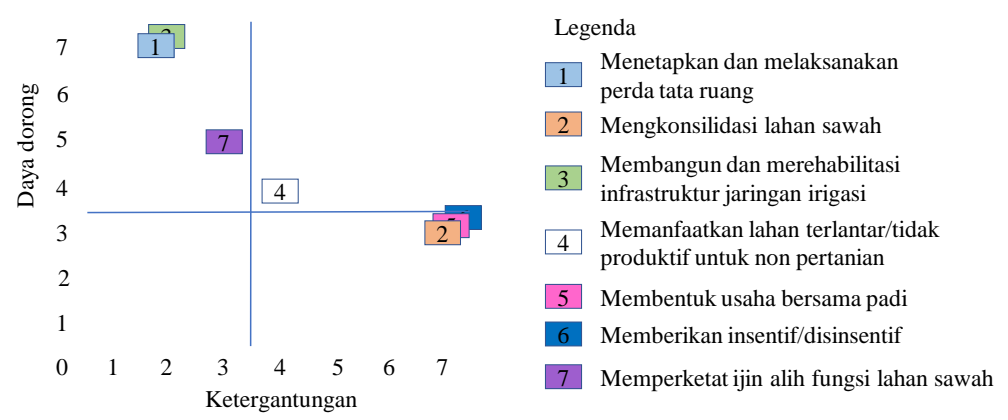

Gambar 7. Diagram pengelompokan sub-elemen dari strategi pengendalian PLTL sawah
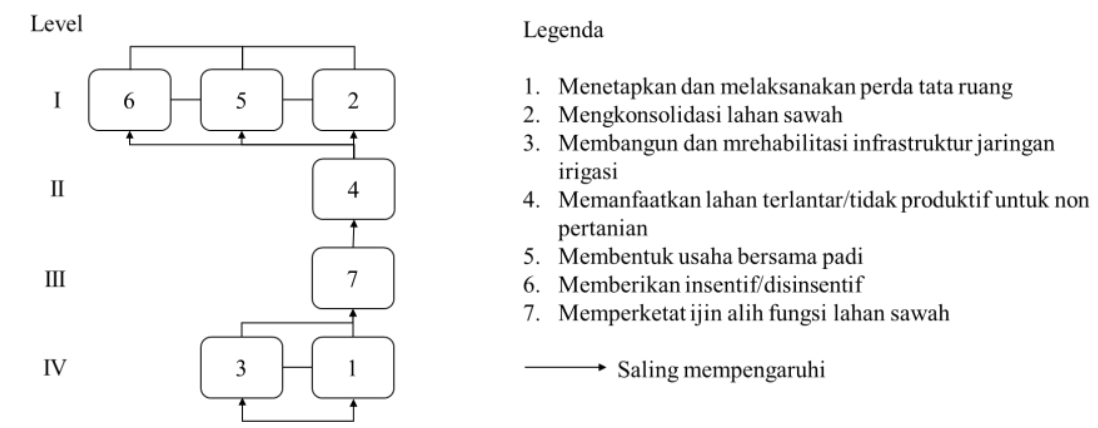

Gambar 8. Model struktur sub elemen kunci strategi untuk mencegah konversi lahan sawah

\subsection{Struktur faktor strategi pencegahan konversi PLTL sawah}

Analisis ISM menghasilkan sub-elemen "menetapkan dan melaksanakan perda tata ruang" dan sub-elemen "membangun dan merehabilitasi jaringan irigasi" sebagai sub-elemen kunci karena mempunyai daya dorong yang tinggi serta ketergantungan yang rendah terhadap sub-elemen lainnya (Gambar 7). Kedua sub-elemen tersebut menempati kuadran empat pada diagram pengelompokan sub-elemen strategi pengendalian konversi PLTL sawah. Prioritas kedua adalah dengan memperketat ijin alih fungsi lahan sawah. Sub-elemen "memperketat ijin alih fungsi lahan sawah" mempunyai daya dorong yang cukup tinggi dan ketergantungan yang relatif rendah. Hal ini berarti komitmen pemerintah melalui pengetatan ijin alih fungsi lahan sawah sangat dibutuhkan (Sumaryanto et al. 2001) agar dapat mendorong strategi lain dalam pencegahan konnversi PLTL sawah. Prioritas berikutnya adalah "memanfaatkan lahan terlantar/tidak produktif untuk non pertanian", "mengkonsolidasai lahan sawah", "membentuk usaha bersama padi", dan "memberikan insentif/disinsentif". Sub-elemen mewakili prioritas penanganan dari upaya pencegahan konversi PLTL sawah yang tergambar pada struktur tingkatan prioritas pencegahannya (Gambar 8). Subelemen "menetapkan dan melaksanakan perda tata ruang" dan sub-elemen "membangun dan merehabilitasi jaringan irigasi" menempati posisi teratas yang dapat mempengaruhi sub-elemen lainnya. Gambar 8 menunjukkan bahwa upaya pencegahan konversi PLTL sawah harus dilakukan dengan melaksanakan kedua sub elemen tersebut.

Strategi pencegahan konversi PLTL sawah membutuhkan instrumen tentang regulasi tata ruang sampai tingkat kabupaten yang berfungsi untuk mengarahkan kebijakan tata kelola ruang agar termanfaatkan sesuai dengan peruntukannya. Pelaksanaan regulasi tata ruang membutuhkan konsistensi pemerintah daerah dalam mengarahkan landscape wilayah yang sesuai dengan Rencana Tata Ruang Wilayah (RTRW) (Prihatin, 2015). Berdasarkan pendapat pakar, penelitian ini memperoleh rekomendasi upaya pencegahan konversi PLTL sawah menjadi non-sawah yang membutuhkan penetapan dan pelaksanaan Perda tata ruang. Ketegasan ini diperlukan untuk menetralisir kebijakan pemerintah daerah yang cenderung berorientasi pada kepentingan jangka pendek dibanding kepentingan jangka panjang. Pemeritah, baik pusat maupun daerah telah mengantisipasi terjadinya konversi PLTL sawah ke non-sawah dengan menerbitkan berbagai kebijakan seperti perlindungan lahan pangan berkelanjutan (UU No. 41 tahun 2009) dan RTRW Kabupaten. Namun kebijakan ini belum membuahkan hasil yang maksimal karena adanya berbagai kepentingan dan kebijakan yang masih tumpang tindih (Barus et al. 2012).

PLTL sawah beririgasi teknis mempunyai ketergantungan penyediaan air untuk produksi padi. Kurang berfungsinya sebagian atau seluruh sistem jaringan irigasi dapat menyebabkan terganggunya proses produksi padi. Hal tersebut dapat menyebabkan beralihnya fungsi sawah untuk memproduksi padi menjadi peruntukan lainnya yang lebih menguntungkan. Dalam upaya pencegahan konversi sawah, Pemda Subang membangun jaringan irigasi di empat kecamatan yaitu Pamanukan, Pusakanagara, Pusakajaya, dan Legon Kulon pada total luas 11.250 hektar (Diperta, 2015). Perbaikan sistem irigasi tersebut meningkatkan IP dari 1-1.5 menjadi IP 2-3 dengan produksi padi dari 3-5 ton per hektar menjadi 58 ton per hektar. Peningkatan produksi padi diharapkan 
dapat meningkatkan pendapatan petani dari usaha tani padi. Keputusan petani untuk mengkonversi lahan sawahnya berbanding terbalik dengan keberlangsungan usaha tani padi (Pewista, 2013), sehingga peningkatan pendapatan petani mendorong petani untuk tidak mengkonversi lahan sawahnya.

\section{Kesimpulan}

Analisis perubahan PLTL lahan secara spasial tahun 1999, 2004, 2009, dan 2014 menunjukkan bahwa PLTL sawah terus menyusut dengan pola perubahan terkonversi menjadi lahan perkebunan atau lahan terbangun.

Faktor utama penyebab terjadinya konversi lahan sawah adalah peningkatan kebutuhan ekonomi petani. Pertumbuhan pemukiman, pertumbuhan pusat ekonomi, pertumbuhan jalur transportasi juga berkontribusi pada terjadinya konversi lahan sawah. Selain itu, peningkatan harga jual lahan yang diakibatkan oleh munculnya sub-elemen tersebut juga mengakibatkan konversi lahan sawah. Berkurangnya animo generasi penerus untuk bertani juga menyebabkan terjadinya konversi lahan sawah. Peningkatan status lahan yang diakibatkan oleh bagi waris maupun jual beli juga mengakibatkan terjadinya perubahan penggunaan lahan sawah menjadi penggunaan lainnya.

Sebagai upaya pencegahan konversi lahan sawah, seluruh stakeholder harus membangun dan merehabilitasi infrastruktur jaringan irigasi dan menetapkan tata ruang daerah. Dalam pelaksanaannya pihak pemerintah harus memperketat ijin perubahan penggunaan lahan sawah menjadi penggunaan lainnya. Keperluan lahan non pertanian dapat memaksimalkan lahan-lahan terlantar yang tidak diusahakan untuk keperluan apapun. Di sisi produksi padi, pemerintah wajib memberikan insentif/disinsentif bagi petani yang melakukan usaha tani padi. Untuk kelayakan usahatani padi di lahan yang sempit, maka diperlukan konsolidasi lahan bagi kepemilikan lahan yang sempit untuk membentuk usaha tani bersama. Upaya pencegahan konversi PLTL sawah membutuhkan Perda Tata Ruang yang harus dilaksanakan secara tegas. Perbaikan infrastruktur jaringan irigasi merupakan prioritas utama untuk mencegah terjadinya konversi PLTL sawah.

\section{Daftar Pustaka}

[1] Andalusia K, D. R. Panuju, B. H. Trisasongko, 2014. Dinamika Perubahan Penggunaan Lahan di Kabupaten Subang. SNIJA. pp. 289-295.

[2] Ashari, 2003. Tinjauan Tentang Alih Fungsi Lahan Sawah ke Non Sawah dan Dampaknya di Pulau Jawa. Forum Penelitian Agro Ekonomi. 21(2), pp. 83-98.

[3] Asmani N, 2013. Pengelolaan Sumberdaya Alam Lestari Melalui Usaha Pertanian Pangan Sistem Korporasi (Sustainable Corporate Farming) Dalam Kerangka REDD+. Prosiding Seminar Nasional Perhepi Kemitraan dalam Pengembangan Agribisnis Sumberdaya Lokal. pp. 91-96.
[4] Attri R, N. Dev, V. Sharma, 2013. Interpretive Structural Modelling (ISM) approach: An Overview. Research Journal of Management Sciences. 2(2), pp. 3-8.

[5] Azar A. dan K. Bayat, 2013. Designing a model for "Business process-orientation" using interpretive structural modeling approach (ISM). Academic Journals. 7(26), pp. 2558-2569.

[6] [Bakosurtanal] Badan Koordinasi Survei dan Pemetaan Nasional, 2009. Peta Rupa Bumi Indonesia skala 1:25.000, Bogor. Bakosurtanal.

[7] [BIG] Badan Informasi Geospasial, 2014. Peta Tutupan Lahan skala 1:50.000, Bogor. BIG.

[8] [BIG] Badan Informasi Geospasial, 2016. Batas Administrasi Kabupaten 1:25.000, Bogor. BIG.

[9] [BPN] Badan Pertanahan Nasional, 2009. Peta Tutupan Lahan skala 1:50 000, Jakarta. BPN.

[10] [BPS Jabar] Badan Pusat Statistik Provinsi Jawa Barat, 2012. Jawa Barat dalam Angka, Bandung. BPS Jabar.

[11] [BPS Subang] Badan Pusat Statistik, 2014. Subang dalam angka 2014, Subang. BPS Subang.

[12] [BPS] Badan Pusat Statistik, 2015. Statitik Indonesia, Jakarta. BPS.

[13] Barus B, D. R. Panuju, K. Munibah, L. S. Iman, B. H. Trisasongko, N. Widiana, R. Kusumo, 2012. Model Pemetaan Sawah dan Perlindungan Lahan Pertanian Pangan dengan Penginderaan Jauh dan Sistem Informasi Geografis (Model of Rice Field Mapping and Its Protection using Remote Sensing and GIS). Seminar dan Ekspose Hasil Kegiatan dan Penelitian P4W LPPM-IPB.

[14] Beuchle R, R. C. Grecchi, Y. E. Shimabukuro, R. Selige, H. Eva, E. Sano, Achard F, 2015. Land cover changes in the Brazilian Cerrado and Caatinga biomes from 1990 to 2010 based on a systematic remote sensing sampling approach. Applied Geography. 58. pp. 116-127.

[15] Congalton R. G. dan K. Green, 2008. Assesing the Accuracy of Remotely Sensed Data, Bukaraton. CRC Press.

[16] Chen S. P. dan W. Y. Wu, 2010. A systematic procedure to evaluate an automobile manufacturer-distributor partnership. European Journal of Operational Research. 205, pp. 687-698.

[17] Darwis W, 2008. Keragaan Penguasaan Lahan Sebagai Faktor Utama Penentu Pendapatan Petani. Seminar Nasional Dinamika Pembangunan Pertanian dan Perdesaan: Tantangan dan Peluang bagi Peningkatan Kesejahteraan Petani, Bogor. PSE. pp. 1-18.

[18] [Diperta] Dinas Pertanian Subang, 2015. Laporan Tahunan. Subang. Diperta.

[19] Disperati L dan S. G. P. Virdis, 2015. Assessment of land-use and land-cover changes from 1965 to 2014 in Tam Giang-Cau Hai Lagoon, central Vietnam. Applied Geography. 58: pp. 4864.

[20] Eriyatno, 2013. Ilmu Sistem, Surabaya. Guna Widya.

[21] Ganasria B. P. and G. S. Dwarakisha, 2015. Study of land use/land cover dynamics through classification algorithms for Harangi catchment area, Karnataka State, INDIA. Aquatic Procedia, 4, pp. 1413-1420.

[22] George J. P. dan V. R. Pramod, 2014. An Interpretative Structural Model (ISM) Analysis Approach in Steel Mills (SRRMs). International Journal of Research in Engineering \& Technology. 2(4): pp. 2347-4599.

[23] Govindan K., D. Kannan, A. N. Haq, 2010. Analyzing supplier development criteria for an automobile industry. Industrial Management \& Data Systems. 110(1): pp. 43-62.

[24] Govindan K., M. Palaniappan, Q. Zhu, D. Kannan, 2012. Analysis of third party reverse logistics provider using interpretive structural modeling. Int. J. Production Economics. 140, pp. 204-211. 
[25] Hidayati H. N. dan R. A. Kinseng, 2013. Konversi Lahan Pertanian dan Sikap Petani di Desa Cihideung Ilir Kabupaten Bogor. Jurnal Sosiologi Pedesaan. 01(03), pp. 222-230.

[26] Irawan B, 2005. Konversi Lahan Sawah: Potensi, Pola Pemanfaatannya, dan Faktor Determinan. Forum Penelitian Agro Ekonomi. 23(1), pp.1-18.

[27] Jadhav J. R., S. S. Mantha, S. B. Rane, 2015. Analysis of interactions among the barriers to JIT production: interpretive structural modelling approach. J Ind Eng Int.11: pp. 331-352.

[28] Janes F. R., 1988. Interpretive structural modelling (ISM): a methodology for structuring complex issues. Trans Inst MC. 10(3). Available at http://sorach.com/items/ismjanes.pdf (Accessed August 21, 2014)

[29] Jauhari A. dan Ritohardoyo S, 2013. Dampak Pembangunan Perumahan Terhadap Perubahan Penggunaan Lahan dan Kondisi Sosial-Ekonomi Penjual Lahan di Kecamatan Mlati. Jurnal Bumi Indonesia. 2(2): pp. 192-201

[30] Kannan G., S. Pokharel, P. S. Kumar, 2009. A hybrid approach using ISM and fuzzy TOPSIS for the selection of reverse logistics provider. Resources, Conservation and Recycling. 54, pp. 28-36.

[31] Khan I. dan Rahman Z., 2015. Brand experience anatomy in retailing: An interpretive structural modeling approach. Journal of Retailing and Consumer Services. 24: pp. 60-69.

[32] Kulsum U., B. Arifin, Z. Abidin, 2015. Determinan Kepurusan Petani Terhadap Konversi Lahan Sawah Menjadi Pemukiman. JIIA. 3(2), pp.187-194.

[33] Kusumaningtyas R. dan I. Chofyan, 2013. Pengelolaan Hutan dalam Mengatasi Alih Fungsi Lahan Hutan di Wilayah Kabupaten Subang. Jurnal, pp.8-19.

[34] Lin L. Z. dan H. R. Yeh, 2013. Analysis of tour values to develop enablers using an interpretive hierarchy-based model in Taiwan. Tourism Management. 34, pp.133-144.

[35] Luthra S., V. Kumar, S. Kumar, A. Haleem, 2011. Barriers to implement green supply chain management in automobile industry using interpretive structural modeling technique-An Indian perspective. Journal of Industrial Engineering and Management. 4(2): pp. 231-257.

[36] Muta'ali L, 2013. Penataan Ruang Wilayah Kota (Tinjauan Normatif - Teknis), Yogyakarta (ID). Badan Penerbit Fakultas Geografi UGM.

[37] Pasandaran E, 2006. Alternatif Kebijakan Pengendalian Konversi Lahan Sawah Beririgasi di Indonesia. Jurnal Litbang Pertanian. 25(4), pp. 123-129.

[38] [Pemda Subang] Pemerintah Daerah Kabupaten Subang, 2009. Peraturan Daerah Kabupaten Subang No 4 Tahun 2009 Tentang Rencana Pembangunan Jangka Menengah Daerah Kabupaten Subang Tahun 2009-2014, Subang. Pemda Subang.

[39] Pewista I dan R. Harini, 2013. Faktor dan Pengaruh Alih Fungsi Lahan Pertanian Terhadap Kondisi Sosial Ekonomi Penduduk di Kabupaten Bantul. Kasus Daerah Perkotaan, Pinggiran dan Pedesaan Tahun 2001-2010. Jurnal Bumi Indonesia. 2(2), pp. 96-103.

[40] Prihatin R. B., 2015. Alih Fungsi Lahan di Perkotaan (Studi Kasus di Kota Bandung dan Yogyakarta). Aspirasi. 6(2), pp. 105-118

[41] Rustiadi E., S. Saefulhakim, D. R. Panuju, 2001. Perencanaan dan Pengembangan Wilayah, Jakarta. Crestpent Press dan Yayasan Obor Indonesia.

[42] Saxena J. P., Sushil, P. Vrat, 1992. Scenario Building: A Critical Study of Energy Conservation in the Indian Cement
Industry. Technology Forecasting and Social Change. 41, pp. 21-146.

[43] Shahabadkar P., S. S. Hebbal, S. Prashant, 2012. Deployment of Interpretive Structural Modeling Methodology in Supply Chain Management - An Overview. International Journal of Industrial Engineering and Production Research. 23(3), pp.195-2005.

[44] Sinuraya J. F, N. K. Agustin, S. M. Pasaribu, 2011. Konsolidasi Lahan Pertanian Pangan: Kasus di Provinsi Jawa Tengah. Di dalam: S. M. Pasaribu, H. P. Saliem, H. Soeparno, E. Pasandaran, F. Kasryno (Editor), Konversi Dan Fragmentasi Lahan Ancaman Terhadap Kemandirian Pangan, Bogor, PT Penerbit IPB Press.

[45] Sohani N. dan N. Sohani, 2012. Developing Interpretive Structural Model for Quality Framework in Higher Education: Indian Context. Journal of Engineering, Science \& Management Education. 5(II), pp. 495-501.

[46] Sudaryanto T. dan I. W. Rusastra, 2006. Kebijakan Strategis Usaha Pertanian Dalam Rangka Peningkatan Produksi dan Pengentasan Kemiskinan. Jurnal Litbang Pertanian. 25(4), pp.115-122.

[47] Sumaryanto, S. Friyatno, B. Irawan, 2001. Konversi Lahan Sawah ke Penggunaan Non Pertanian dan Dampak Negatifnya. Prosiding Seminar Nasional Multifungsi Lahan Sawah. pp. 1-18.

[48] Suradisastra K. dan H. P. Saliem, 2011. Di dalam: Pasaribu SM, Saliem HP, Soeparno H, Pasandaran E, Kasryno F (Editor). Konversi Dan Fragmentasi Lahan Ancaman Terhadap Kemandirian Pangan. Bogor, PT Penerbit IPB Press.

[49] Sushil, 2012. Interpreting the Interpretive Structural Model. Global Journal of Flexible Systems Management: 13(2): pp. 87-106.

[50] Terra T. N., R. Ferreira dos Santos, D. C. Costa, 2014. Land use changes in protected areas and their future: The legal effectiveness of landscape protection. Land Use Policy. 38, pp. 378-387.

[51] Widiatmaka, W. Ambarwulan, K. Munibah, P. B. K. Santoso, 2013. Analisis Perubahan Penggunaan Lahan Dan Kesesuaian Lahan Untuk Sawah Di Sepanjang Jalur Jalan Tol JakartaCikampek Dan Jalan Nasional Pantura, Kab. Karawang. Prosiding Seminar Nasional \& Forum Ilmiah tahunan Ikatan Surveyor Indonesia (FIT-ISI). pp. 7-14.

[52] Widiatmaka, W. Ambarwulan, P. B. K. Santoso, S. Sabiham, Machfud, M. Hikmat, 2016. Remote sensing and land suitability analysis to establish local specific inputs for paddy fields in Subang, West Java. Procedia Environmental Sciences. 33, pp. 94-107.

[53] Zakaria A. K. dan B. Rachman, 2013. Implementasi Sosialisasi Insentif Ekonomi dalam Pelaksanaan Program Perlindungan Lahan Pertanian Pangan Berkelanjutan. Forum Penelitian Agro Ekonomi. 31(2), pp. 139-149.

[54] Zhu Z. and C. E. Woodcock, 2014. Continuous change detection and classification of land cover using all available Landsat data. Remote Sensing of Environment.144. pp. 152171.

[55] [UU] Undang-undang, 2009. Undang-undang Nomor 41 tentang Perlindungan Lahan Pertanian Pangan Berkelanjutan.

[56] [PP] Peraturan Pemerintah, 2012. Peraturan Pemerintah Nomor 12 Tentang insentif perlindungan lahan pertanian pangan berkelanjutan. 